\title{
The Impact of Open Selection on the Number of Corruption Cases in High Leadership Positions (JPT) in Local Governments in Indonesia
}

\author{
Winda Hestiecia \\ Department of Economic Planning and Development Policy, Faculty of Economics and \\ Business, Universitas Indonesia.
}

*Correspondence : windahestiecia@gmail.com

\section{ARTICLE INFO}

\section{Article History}

Submited; May 28, 2021

Revised; June 16, 2021

Accepted; June 29, 2021

Available online: July 08, 2021

\section{Keyword}

Open Selection

Corruption

High Leadership

Positions

\begin{abstract}
This study aims to explain the impact of implementing open selection on reducing the amount of corruption cases of high leadership position (JPT) in local government in Indonesia. Using the differencein-differences-in-differences (DDD) approach, this study analyzes panel data on JPT corruption in Indonesia that have been inkracht handled by the Corruption Eradication Commission (KPK) in the period 2009-2019. The results of theoretical studies and previous research have given rise to the hypothesis that the implementation of open selection has a positive impact on reducing JPT corruption cases in local governments in Indonesia. This study found that the implementation of open selection can reduce the number of corruption cases by $-0.892 \%$ and significantly at the $10 \%$ alpha level in regions with high total capital expenditures. This finding demonstrates the positive impact of open selection on JPT corruption cases and thus supports previous studies on the positive impact of implementing a merit system, in particular open selection on the number of JPT corruption cases in regions with high total spending. In addition, to strengthen the research results by adding case studies and in depth interviews with KASN and ICW. It was found that the role of regional politics greatly influenced the implementation of open selection. It is the high political costs in the regions that are the main cause that causes corruption of governors, mayors and regents followed by regional officials to continue to occur.
\end{abstract}

\section{INTRODUCTION}

The The phenomenon of corruption in Indonesia is the main obstacle in realizing government bureaucracy and quality public services (Kasim, 2013). In addition, corruption and inefficient government are also obstacles to the Indonesian economy, especially business development and investment (World Bank, 2019). To create a clean and efficient bureaucracy, the government has begun to pay attention to the resources of its apparatus, in particular creating bureaucratic leaders who have high competence, professionalism and integrity and can prevent corrupt behavior (Dwiputrianti, 2018). Based on Law Number 5 of 2014 concerning the State Civil Apparatus (UU ASN), the government seeks to implement a merit 
system in ASN policy and management with the aim of transforming from an administrative and rule-based bureaucracy to a performance-based one. Countries that implement a merit system will place bureaucratic posts in accordance with their competencies and can improve public services (McCourt, 2007; Suyito et al., 2018). In addition, the implementation of recruitment based on a merit system in the bureaucracy can reduce corruption because bureaucrats are selected through an open and transparent selection (Dahlström et al., 2012; Rauch \& Evans, 2000).

The Corruption Eradication Commission (KPK) noted that during 2009 to 2019 perpetrators of criminal acts of corruption based on professions that had been terminated with permanent legal force (inkracht), high-ranking officials ranked 3rd as many as 168 cases after the private sector which ranked first with 274 cases and member of the DPR/DPRD who ranks second with 248 cases. This illustrates cases of corruption committed by high-ranking officials in Indonesia is still high and the selection process for bureaucratic officials carried out in Indonesia has not been able to produce officials who are clean and free from corrupt behavior. In addition, based on a study by the State Civil Apparatus Commission (KASN) (Katharina, 2018), the potential loss to the state from corrupt practices carried out by bureaucratic officials to obtain positions through the practice of buying and selling positions reaches IDR 102 trillion involving 600 central and regional agencies. The State Civil Apparatus Commission (2019) in its report also stated that there are still many regions that have not implemented the KASN recommendations in implementing the merit system in ASN management.

The merit system assessment conducted by KASN noted that most local governments have not implemented a merit system in the management of their employees and are categorized as poor and not good. A total of $20.6 \%$ of the provincial government got a bad score and $61.8 \%$ got a low score. Only $17.6 \%$ of the provincial government got a good score. While for the Regency and City governments, $31.1 \%$ of the government got a bad score and $55.3 \%$ got a low score. Only $11.7 \%$ of district and city governments got a good score and $1.9 \%$ got a very good score. This encourages the government to create bureaucratic leaders who are competent, professional and have integrity. The government through Law Number 5 of 2014 concerning State Civil Apparatus (UU ASN) seeks to implement a merit system in US policy and management. On the central and local governments. One form of implementing the merit system is the implementation of a competitive open selection for filling high leadership positions (JPT). Based on the ASN Law, the High Leadership Position is a group of high positions in government agencies. High Leadership Positions (JPT) consist of:

1. JPT Utama as a substitute for echelon I positions occupying the head of an agency in the central government;

2. JPT Madya as a substitute for echelon I positions in the central and provincial governments; and

3. JPT Pratama as a substitute for echelon II positions in the central and provincial / district / city governments.

The implementation of bureaucratic reform in Indonesia is inseparable from improving government towards good governance and creating a bureaucracy that is free from corruption, collusion and nepotism (KKN). The open career system aims to prevent deviant practices such as "sharing" positions to family and relatives in filling positions and conflicts of interest. That's why KASN was formed to monitor the implementation of the open selection (Nasir, 2019). Implementation of open selection and fair competition will ensure employee performance (Tong et al., 1999). Open selection is more "popular" than other aspects of the merit system and ASN management because open selection directly targets placing the right people according to the needs of the organization, eliminating abuse of authority, favoritism, closeness, and preventing corruption (Hotho et al., 2018).

Open selection has only been carried out in Indonesia since 2017. Because 2014 to 2016 is the year of socialization and many regions are not ready to carry out open selection both in terms of management and budget. By the time the ASN Law was enacted in 2014, the preparation of the budget for 2015 had already been completed, while the implementation of this open selection involved external parties which required large costs. Therefore, the 
implementation of open selection for JPT Madya and JPT Pratama was only implemented in 2017 and there are still not many regions that carry out open selection. The number of regions that carry out open selection continues to increase from 2017 to 2019. At the beginning of 2017 there were only 18 regional governments that carried out open selection, followed by 2018 as many as 43 regional governments and 2019 as many as 119 regional governments. This increase illustrates that local governments are starting to implement the ASN Law and KASN recommendations to fill official positions through a merit system, namely open selection.

The implementation of the merit system in the bureaucracy in Indonesia is inseparable from the quality of Indonesian government. Based on data from the (World Bank, 2019), the quality of Indonesian government continues to improve, but is still low compared to other Asian countries. Based on World Economic Forum (WEF) data, Indonesia's Government Effectiveness Index (GEI) increased from 0.04 and ranked 84th to 0.18 in 2019 and climbed to 75th rank. In relation to corruption, by looking at Indonesia's Corruption Perceptions Index (CPI) published by Transparency International shows a positive trend from year to year. In 2019, Indonesia's CPI increased by 2 points from 38 to 40 points compared to the previous year. In order to reduce the level of corruption, Indonesia needs to continue to improve the quality of its government.

Several studies on the implementation of the merit system and its relation to corruption, collusion and nepotism (KKN) have been conducted. However, there is no agency that has valid and reliable data regarding collusion and nepotism practices such as corruption at the KPK. Therefore, the study in this research focuses on open selection and its relation to corruption which is also a problem in the bureaucracy in Indonesia. A study conducted by (Dahlström et al., 2012) which combines bureaucratic and political factors to see which factors reduce corruption. It was found that a professional bureaucracy can reduce corruption because it creates a separation of interests between bureaucrats and politicians. This study continues research conducted by (Rauch \& Evans, 2000) which analyzes three components of the Weberian bureaucracy that can reduce corruption.

It was found that from several bureaucratic indicators, recruitment based on a merit system had an effect on reducing corruption, while other bureaucratic factors that were thought to be relevant, such as competitive salaries of civil servants, career stability, or internal promotions, did not have a significant impact. In line with the opinion of the World Bank (2019) in a strategy for comprehensive eradication of corruption, there are three important components, including recruitment based on a merit system, authority control and strengthening supervision and implementing punishment mechanisms. found that the recruitment and selection process was not based on the principle of merit, which was characterized by a list of formations that were not based on bureaucratic needs, indications of corruption, collusion, and nepotism.

Research on the impact of implementing open selection on the number of JPT corruption cases in Indonesian local governments is still very limited. Until this research was conducted, there was no research that looked at the direct impact of the application of the merit system, especially open selection, on the number of corruption JPT cases in Indonesian local governments. The selection of JPT is also based on (Tiiptoherijanto, 2019) that the occurrence of corruption tends to be greater by senior officials than juniors because opportunities are more open. In addition, strong leadership in bureaucratic reform is very important. Bureaucratic officials are responsible for their professional colleagues or the public at large (Alesina \& Tabellini, 2007). Based on the above background, this study aims to identify the extent to which the impact of implementing a merit system, especially open selection, can reduce the amount of JPT corruption in Indonesian local governments.

The merit system according to (Rossen, 1975) is a fair and orderly process for hiring, paying, developing, promoting, retaining, disciplining, and recruiting people based on their abilities and performance. Then (Kellough, 1999) defines merit as a series of policies and procedures in fulfilling a job. According to (McCourt, 2007) explains that the notion of merit is placing the "best person" for a job. The principle of merit has become an important term as the basis of anti-discrimination policies and regulations and particularly in affirmative action in 
the workplace. Then (McCrudden, 1998) said that sometimes placing people who are not very competent but have high productivity is a more appropriate policy than placing someone with high competence but low productivity. In Indonesia, the merit system is defined in Law Number 5 of 2014 concerning State Civil Apparatus and Government Regulation Number 11 of 2017 concerning Management of Civil Servants as ASN policy and management based on qualifications, competence, and performance in a fair and reasonable manner without discriminate against political background, race, color, religion, origin, gender, marital status, age, or disability.

Meanwhile, the State Civil Apparatus Commission (2019) in its study defines the principle of merit, basically, that an employee must be selected and promoted based on their ability to do the job. Since the enactment of the ASN Law in 2014, the application of a merit system in ASN management has become an obligation for all governments at the central and regional levels. In addition, PP No 11 of 2017 concerning Civil Servants states that career development, competency development, career patterns, transfers, and promotions must be carried out by applying the principle of the merit system. Based on the ASN Law, one of the policies to achieve a merit system in ASN management in Indonesia is the implementation of an open selection for high leadership positions (JPT).

The purpose of open selection is to be able to recruit ASN officials with high integrity, professionalism and place them in government bureaucratic posts according to their competence; ensure that $A S N$ receive fair and reasonable compensation; develop ASN capabilities through guidance and training; and protect ASN careers from politicization and policies that are contrary to merit principles such as nepotism and favoritism (Dwiputrianti, 2018). Furthermore, open selection is a form of application of the merit system that has been implemented in Indonesia which can be measured and monitored by KASN. The policy aims to obtain competent, neutral, high-performing high-ranking officials who can encourage increased performance of the government bureaucracy. Thus, open selection is one of the policies that are expected to reduce corrupt practices (State Civil Apparatus Commission, 2019).

\section{RESEARCH METHODS}

This research method uses a combination research method (Mixed Methods). The combination research method is a research method that uses two methods, namely quantitative and qualitative research. This method is used to obtain more comprehensive, valid, reliable, and objective data (Creswell, 2013). Creswell found that there are several combination methods. In this study, the combination method used is a sequential explanatory model combination. In this model, data collection and analysis of quantitative data are carried out in the first stage, followed by qualitative data collection and analysis in the second stage by adding case studies and interviews to strengthen the results of the quantitative research conducted in the first stage. This study uses a difference-in-difference-in-difference (DDD) approach to see the impact of applying open selection on JPT corruption. Through the DDD approach, this study evaluates the effects of the application of the ASN Law, especially in regions that have implemented open selection.

This approach requires recording the situation in two time periods, namely before and after treatment (treatment) with reference to the difference in its impact on the treatment group (treatment group) compared to the control group (control group). To get the effect of applying open selection to JPT, this study follows (Paul, 2011) to see the effect of the ASN Law on regions that have implemented open selection as a treatment group and regions that have not implemented open selection as control groups. The DDD regression model below explains that the variable number of corruption cases of JPT Inkracht in each regional entity $i$ in the period $t$ year, is a function of merit, open selection dummy, total expenditure, interaction of dummy merit with total expenditure, interaction of dummy merit, open selection with total expenditure and control variables (average salary of employees) at the time of the corruption case. 
The equations for the basic DDD model are:

Corruption $=0+1$ year of open selection +2 area of open selection + 3 years of open selection $x$ area of open selection $+\beta 4$ years of open selection $x$ open selection area $x$ total capital expenditure +5 total capital expenditure

6 controlite $+\mathrm{i}+\mathrm{t}+\varepsilon \mathrm{it}$

Where:

- Corruption is the number of corruption cases in high leadership positions in the regions based on the corrupted fiscal year for each regional government entity $i$ in period $t$;

- The year of open selection is a dummy for the implementation of the open selection policy for each regional government entity $i$ in period $t$ which has a value of 1 for the year after the implementation of the open selection and the years after that and 0 for the years before the implementation of the open selection;

- An open selection area is a dummy for an area that has carried out an open selection for each regional government entity $i$ in period $t$ which has a value of 1 for the year the open selection is implemented and 0 for the year that has not implemented an open selection;

- Total capital expenditure is total capital expenditure (IDR) in log based on the corrupted fiscal year for local government entity $i$ in period $t$;

- The control variable is the average salary of ASN based on the corrupted fiscal year in regional government entity i in period $t$;

- Is fixed effects; $t$ is the year effects and it is the error term for each number of cases of corruption of high-ranking officials based on the corrupted fiscal year for local government entity $\mathrm{i}$ in period $\mathrm{t}$.

In addition to the main model, to identify the effect of the application of open selection on JPT corruption, it is necessary to prove that there is a similar trend in the number of corruption cases in the treatment group and the control group before the implementation of open selection. With the similarity of trends before the policy, the difference in the trend of the number of corruption cases after the implementation of open selection between the treatment group and the control group can be claimed as the effect of the implementation of the open selection. The assumption of this common pre-treatment trend is the basis for the use of the difference-in-differences approach. Following Gultom (2019), this study tested the common pre-treatment trend using the basic regression equation model:

\section{Corruption it $=\beta 0+\beta 1$ Time Rescale $+\beta 2$ Time Rescale $x$ \\ Daerah Seleksi Terbuka it $+\gamma i+\delta t+\varepsilon i t$}

Where the number of corruption cases of JPT inkracht based on the corrupted fiscal year for region $i$ in period $t$; is a dummy time rescale variable for each region, where 0 is the first year of applying open selection $-1,-2,-3$, etc. are years before the implementation of open selection in each province, and 1,2, 3, etc. is the opposite; The Open Selection Area is a dummy area that has carried out an open selection. Coefficient 2 common pre-treatment trend between areas that have implemented open selection (treatment group) compared to areas that have not implemented open selection (control group). The null hypothesis $2=0$ thus relates to the assumption used in the identification strategy of this study, namely that there is a similar trend in the number of corruption cases in the treatment group and the control group before the open selection was carried out.

In order to support the results of quantitative research conducted at an early stage, this research also uses a case study approach to focus on a particular event in order to gain a deeper understanding of an event along with its root causes and objectives. The case study in this study regarding open selection and corruption is the KPK's Hand Arrest Operation (OTT) against the Regent of Jombang, East Java and the Head of the Jombang Health Service who were caught in a bribery case of buying and selling positions in 2018 . The sources used 
are in the form of news that contained in online media from 2017 to 2018 and a content analysis was carried out to get an overview of the case and conclusions from the problems of open selection and corruption in the Jombang regional government. To strengthen the research results, in addition to conducting case studies, the authors conducted interviews with agencies that have the authority to regulate open selection and independent anti-corruption activist organizations.

\section{RESULT AND DISCUSSION}

\section{Common Pre-treatment Test}

\begin{tabular}{|l|l|}
\hline $\begin{array}{l}\text { Bound Variable: Number of JPT Corruption } \\
\text { Cases }\end{array}$ & $\begin{array}{l}\text { Koefisien } \\
\text { OLS }\end{array}$ \\
\hline $\begin{array}{l}\text { Independent variable: } \\
\text { timerescale }\end{array}$ & -.0005552 \\
& $(.0007882)$ \\
timerescale x open selection $i t$ & .0019637 \\
& $(.0021735)$ \\
N Observation & 5,962 \\
N Groups (Province) & 542 \\
\hline Table 1. Common Pre Treatment Test Results, Source: processed \\
data, 2020
\end{tabular}

Based on the regression results, it can be seen that the interaction open selection it (it2) cannot be distinguished statistically (not significant) with the coefficient .0019637 . Thus, these results indicate that there is a similar trend in the number of JPT corruption in regions that have carried out an open selection with regions that have not carried out an open selection. Given the similarity of trends before the implementation of the open selection policy, the difference in trends after the policy shows the effect of the open selection policy on regions that have implemented open selection.

\section{Impact of Open Selection on the Number of JPT Corruption Cases}

The estimation test begins with determining the best Ordinary Least Square (OLS) regression approach. The best approach is obtained by Pooled Least Square (PLS). However, in data processing can not be separated from the problem of econometric criteria. To overcome the heteroscedasticity problem so that the OLS estimate is not biased, OLS Fixed Effect Robust regression is used. The results obtained in the model (1) without control variables and model (2) with control variables in table 2.

\begin{tabular}{|l|r|r|}
\hline \multicolumn{1}{|c|}{$\begin{array}{c}\text { Variabel Terikat: Jumlah } \\
\text { Kasus Korupsi JPT }\end{array}$} & \multicolumn{2}{|c|}{ Koefisien OLS } \\
\hline & $(1)$ & \multicolumn{1}{c|}{$(2)$} \\
\hline Tahun Seleksi Terbukait & 0.0162735 & 0.0161894 \\
& $(0.0209052)$ & $(0.020892)$ \\
Daerah Seleksi Terbukait & $0.2094187^{*}$ & $0.2044468^{*}$ \\
& $(0.1215196)$ & $(0.1207419)$ \\
Tahun Seleksi Terbukait $\mathrm{X}$ & 0 & 0 \\
Daerah Seleksi Terbukait & $($ omitted) & $($ omitted) \\
& $-0.0089227^{*}$ & $-0.0087365^{*}$ \\
& $(0.0045599)$ & $(0.0045599)$ \\
Tahun Seleksi Terbukait X & & \\
Daerah Seleksi terbukait X & $0.0067097^{* * *}$ & $0.0045295^{*}$ \\
Total Belanja Modalit & $(0.0023931)$ & $(0.0056917)$ \\
& & 0.003509 \\
Total Belanja Modalit & & $(0.0053881)$ \\
\hline
\end{tabular}




\begin{tabular}{|l|r|r|}
\hline \multicolumn{1}{|c|}{$\begin{array}{c}\text { Variabel Terikat: Jumlah } \\
\text { Kasus Korupsi JPT }\end{array}$} & \multicolumn{2}{|c|}{ Koefisien OLS } \\
\hline & \multicolumn{1}{|c|}{$(1)$} & \multicolumn{1}{c|}{$(2)$} \\
\hline Gajiit & 5,962 & 5,962 \\
N Observasi & 542 & 542 \\
N Groups & 0.0626 & 0.0573 \\
R-Squared & & \\
\hline
\end{tabular}

Table 2. Effects of the Implementation of Open Selection on JPT

Corruption.Source: processed data, 2020

Information:

(1) OLS dasar basic equation

(2) OLS basic equation with control variable

Table 2. shows the results of the effect/impact of open selection on the number of JPT corruption cases. Based on the estimation results of the equations in columns 1 to 2 , namely in the OLS equation both in the basic model and after adding control variables, it is seen that the implementation of open selection in total capital expenditures has always consistently reduced the number of JPT corruption cases in regions that have implemented open selection. From the results of the regression between OLS, it is necessary to choose the equation that will be used to answer the research objectives. Therefore, in this study, the equation chosen to answer the research objective is the most complete equation in column 2 (OLS with control variables). From the above test, on the difference-in-differences (DiD) interaction variable between the Open Selection Year x Openit Selection Region the results of the coefficient 3 are omitted, therefore to see the effect of implementing open selection using the coefficient 4 on the difference-in-interaction variable. differences-in-differences (DDD) between Open Selection Years $x$ Open Selection Regions $x$ Total Capital Expenditures, namely the effect of the application of open selection on the number of JPT corruption cases in regions with high total capital expenditures.

The results illustrate that the implementation of an open selection policy in regions that have implemented open selection is able to reduce the number of JPT corruption cases in regions that have high total capital expenditures by $-0.892 \%$ and significant at the $10 \%$ level. This finding demonstrates the positive impact of open selection on the reduction of JPT corruption cases and thus supports previous studies on the positive impact of implementing a merit system, particularly open selection on corruption. These results indicate that the application of a merit system in regions that have a high total capital expenditure value and have carried out an open selection will reduce the number of corruption cases carried out by the JPT because officials are selected through an open, transparent and competitive selection with attention to competence (Dwiputrianti, 2018; Rauch \& Evans, 2000; Schroth, 2006).

In addition, other results show that the Openit Selection Area variable has a positive and significant effect at the 10\% level. Meanwhile, the Openit Selection Year variable also has a positive correlation, but it is not significant. This finding shows that in regions that have implemented open selection, corruption tends to increase. This is inseparable from the role of the KPK in eradicating corruption. From 2017 to 2019, the average addition of cases involving inkracht KPK increased by $21.31 \%$. In addition, the implementation of open selection is inseparable from political factors. The election still depends on the Governor/Mayor/Regent as the Civil Service Supervisor. The trend of corruption of political officials also continues to increase and is followed by local officials under them. This is in line with research which states that the government is dependent on political leaders who are the cause of corruption, so there needs to be control as a deterrent to corruption (Dahlström et al., 2012; Halim, 2008).

The variable of Total Modalite Expenditure which has a positive and significant influence on the number of JPT corruption cases in the regions that have carried out an open selection. 
This is consistent with the initial indication that the larger the government budget/expenditure, especially capital expenditure, the higher the potential for officials to commit corruption (Becker, 1968; Scully, 1991). The use of control variables is carried out to ensure the consistency of research results on the main explanatory variables. The research findings show that the salary received by civil servants has no effect on the number of JPT corruption cases. This finding is in line with the research results of (Gurgur \& Shah, 2005) which did not find a statistically significant relationship between the salary variable and the amount of corruption. This may indicate that the size of the legal income received is not related to the incentives of an official to commit corruption. Other factors outside the economy such as politics and socioculture are also often considered the main causes of someone committing corruption.

\section{Robustness Check}

Robustness Check is used to gain confidence in the model in this study consistently answering research using different alternative models but the goal is the same. The alternative model in this study is to enter the total expenditure on goods and services so that the data used is the total expenditure of capital expenditure and expenditure on goods and services. The results of the robustness check as shown in table 3 . show that the estimation is consistent with the main model, namely equation (2) that the implementation of open selection in regions that have high total capital expenditures and goods and services has a significant effect in reducing the number of JPT corruption cases. The equation model chosen is equation (2) because it has a lower robust standard error than equation (4). It is concluded that model (2) with control variables can be used to answer research questions.

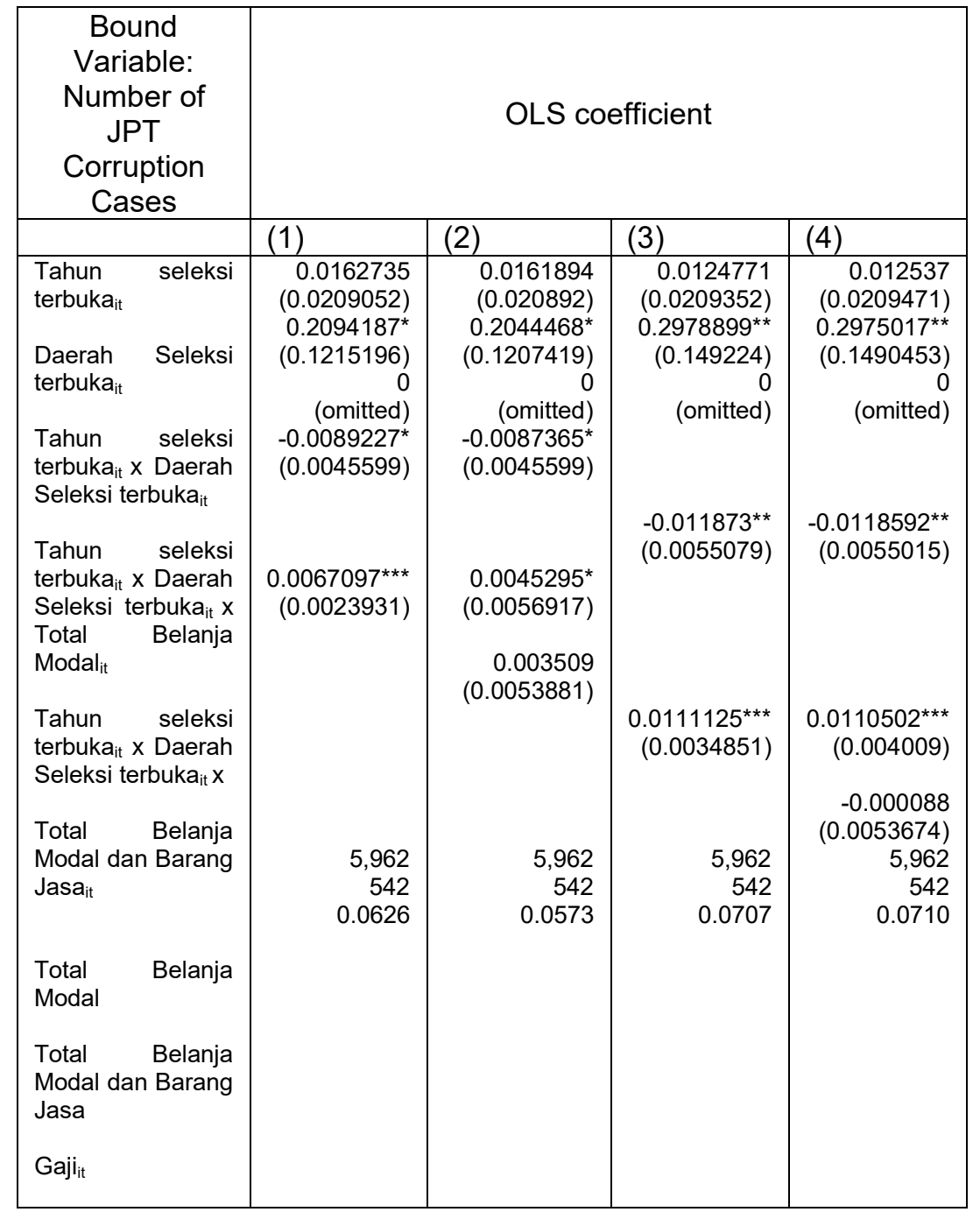




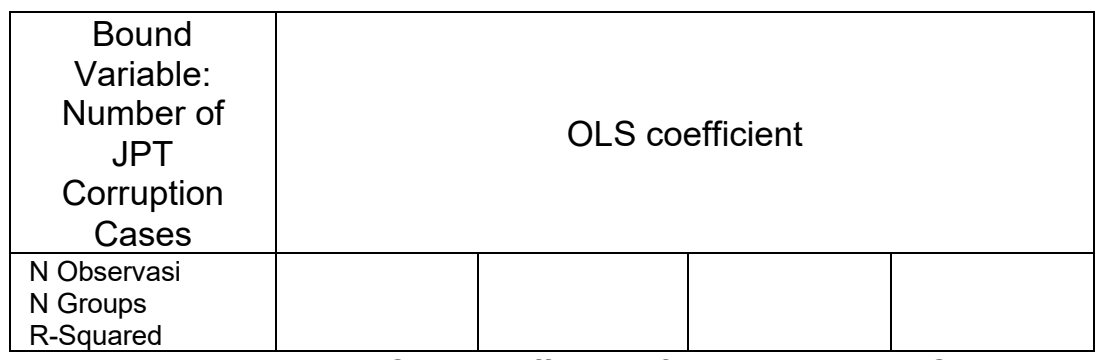

Table 3. Robustness Check Effects of Implementing Open

Selection on JPT Corruption. Source: processed data, 2020

Information:

(1) OLS dasar basic equation

(2) OLS basic equation with control variable

(3) The basic equation of OLS by entering the variable of the ratio of goods and services expenditure

(4) Basic OLS Equation By Incorporating Goods and Services Expenditure Ratio Variables and Control Variables

\section{Case Study Results}

The case study in this study regarding open selection and corruption is the KPK's Hand Capture Operation (OTT) against the Regent of Jombang, East Java and the Head of the Jombang Health Service who were caught in a bribery case of buying and selling positions in 2018. In relation to the implementation of open selection which is a From the focus of this research, it can be seen that the Regent of Jombang who is a PPK is also a political official. This can be related to how the political costs in the regions are very high. As in a study conducted by ICW (2018), the political costs incurred to become governors, regents and mayors require at least Rp. 20 billion to Rp. 30 billion. This causes corrupt behavior, in this case, there is a case of buying and selling positions in the regional apparatus under it.

The Anti-Corruption Education Book Writing Team, states that there are at least 3 factors that cause many officials from political parties to be entangled in corruption cases. First, the dowry in the nomination, so that elected officials will try to restore their political capital. The second is the lavish lifestyle of the officials and the third factor is the apathetic behavior of the people who still ask for money from candidates for regional heads so that they can be elected. This accumulation causes the corrupt practices of regional heads to continue (Yudiatmaja, 2016). The appointment of the head of service, which should be based on a merit system throug open selection, is defeated by money. As long as the political role still plays a role in the implementation of the open selection, cases such as the Jombang Regent will continue to be found. Therefore, improvements in the political sector need to be a concern to create clean regional officials and occupy positions in accordance with qualifications, competencies and performance.

The role of KASN is to ensure the selection process for vacant positions in accordance with the laws and regulations governing staffing. Based on the ASN Law, the merit system is a collaboration between qualifications, competencies and performance appraisals. In the implementation of ASN coaching, these 3 pillars are the main keys, so they are also a reference in the implementation of an open selection to fill the JPT. Found in the regions, the vacant positions are inseparable from the political factors of the officials. Among other things, many officials were rotated, demotion (downgraded positions), and even non-jobs. It is also necessary to examine the background of the panel members, whether they are involved in legislative nominations or affiliation with the PPK and prospective participants. It is hoped that the Pansel is a neutral party in making the selection. In the selection stage it is also not uncommon to find irregularities by playing the requirements in the selection. This results in fewer applicants who will participate, and there are indications from applicants that there are already candidates who will occupy the position. In the assessment and interview stages, it is 
hoped that the candidates will be free from corruption. The authority over which officials will be elected is the authority of the PPK. Values from ranks 1 to 3 will be submitted and it is the PPK's perrogative right to vote. It is hoped that from the selection stage, the PPK will certainly choose number 1, unless there is a special note from the PPK.

An example of a case obtained by KASN and reported to the KPK is a case of selection and buying and selling of positions at the Ministry of Religion. This is a report from KASN because in the open selection process it found many irregularities and the KASN recommendation was not followed up by the PPK. Indications of "proposal" in open selection can also be captured, for example changes in administrative requirements to make it easier for certain people. The role of KDP as a political official is very influential in the apparatus of regional officials. In the case found by KASN in Province $X$, there were officials who were not given jobs because the echelon officials did not support the elected PPK. The recommendation given by KASN is that the weighting of the 3 pillars of the merit system (qualification, competence and performance appraisal) can be evaluated. For example, the administrative selection weight is greater than the performance appraisal, which is of course expected to be more of a concern to be a motivation for other prospective applicants.

Based on the results of an interview with the Head of ICW's Political Corruption Division regarding the implementation of open selection in Indonesia, conceptually it is good, because it creates checks and balances between many stakeholders. Such as the involvement of KASN and regulations in the election of public officials are getting tighter. The concept of open selection was designed to create a better selection method for public officials and was created to build a merit system. With a good aim to answer the challenges and problems of the selection of public officials who are full of Collusion, Corruption, Nepotism (KKN). However, the concept and reality are different. There are many other problems that prevent this positive goal from being achieved.

KASN as a state institution is a quasi-executive or an extension of the President to carry out the duties and authorities as stipulated in the ASN Law. In carrying out their duties, of course, there are challenges and the main problems are 2 things, namely: money and politics. For example, in the case of OTT, the Head of the Jombang Region proved that the selection of public officials was a place to make money. One who has integrity and capacity is defeated by one who has money. This illustrates the money factor can affect the implementation of the selection. In addition, in relation to political factors, in fact many positions in government pay attention to political lines. Like the phenomenon of officials from party $A$, officials below them will tend to be affiliated with party A so that political factors interfere with the initial intention of the open selection itself.

The existence of political factors mixed with the desire to earn money is an implication of high regional political costs. Based on the ICW study, the political costs incurred to become governors, regents and mayors require at least Rp. 20 billion to Rp. 30 billion. The impact of expensive political costs results in corrupt policies to restore these expensive political costs. These include the sale and purchase of land permits, corruption of goods and services. Based on KPK data, $80 \%$ of the total corruption is corruption in the procurement of goods and services. This includes buying and selling public official positions which cannot be separated from expensive politics. For cases that can be taken which are KASN recommendations that are ignored by the Ministry of Religion, the Chair of a Political Party affiliated with the Minister, can influence the decision to implement an open selection within the ministry.

The recommendations given in the implementation of open selection are conceptually good with public participation and checks and balances by KASN. It is necessary to ensure that the steps in the implementation of the open selection are carried out as recommended by the KASN. The recommendations given are more outside the selection mechanism itself, namely the improvement in the political sector in the long term. Because the regional head is a political actor, as long as the political mechanism is not improved, fraud such as the practice of $\mathrm{KKN}$ in the open selection process will continue to occur. As long as the political mechanism in Indonesia is not improved, the positive concept will always be difficult to implement. 


\section{CONCLUSION}

This study shows that the application of open selection has a positive impact on reducing corruption cases in high leadership positions in local government in Indonesia. This study found that the implementation of open selection can reduce the number of corruption cases by $-0.892 \%$ and significantly at the $10 \%$ alpha level in regions with high total capital expenditures. This finding demonstrates the positive impact of open selection on JPT corruption cases and thus supports previous studies on the positive impact of implementing a merit system, particularly open selection on the number of JPT corruption cases in regions with high total spending. In addition, to strengthen the research results by adding case studies and in-depth interviews with KASN and ICW. It was found that the very strong role of regional politics greatly influenced the implementation of open selection. It is the high political costs in the regions that are the main cause that causes corruption of governors, mayors, and regents followed by officials of the regional apparatus below them to continue. This research is limited to data on JPT corruption cases at the KPK and limited to local governments, so it has not described the number of JPT corruption cases in Indonesia and other factors that look at effectiveness of the implementation of open selection in reducing corruption. Thus, further research is needed to include a larger sample such as the central government and the number of JPT corruption cases handled by the Police and the Attorney General's Office.

\section{REFERENCE}

Alesina, A., \& Tabellini, G. (2007). Bureaucrats or politicians? Part I: a single policy task. American Economic Review, 97(1), 169-179. https://doi.org/10.1257/aer.97.1.169

Becker, G. S. (1999). Crime and Punishment: An Economic Approach', Journal of Political Economy. International Library of Critical Writings in Economics, 111, 141-189. https://doi.org/10.1086/259394

Chêne, M. (2019). Successful approaches to tackle petty corruption. Transparency International. https://www.jstor.org/stable/resrep20474

Creswell, J. W. (2013). Research Design: Pendekatan Kualitatif, Kuantitatif, dan Mixed (3rd ed.). Penerbit Pustaka Pelajar.

Dahlström, C., Lapuente, V., \& Teorell, J. (2012). The merit of meritocratization: Politics, bureaucracy, and the institutional deterrents of corruption. Political Research Quarterly, 65(3), 656-668. https://doi.org/10.1177/1065912911408109

Dwiputrianti, S. (2018). Challenges With Implementation Of The Merit System In The Open Recruitment Of Government High Positions: The Case In Indonesia. 2018 Annual Conference of Asian Association for Public Administration:" Reinventing Public Administration in a Globalized World: A Non-Western Perspective"(AAPA 2018), 70-80. https://doi.org/10.2991/aapa-18.2018.8

Gultom, Y. M. L. (2019). Governance structures and efficiency in the US electricity sector after the market restructuring and deregulation. Energy Policy, 129, 1008-1019. https://doi.org/10.1016/i.enpol.2019.02.005

Gurgur, T., \& Shah, A. (2005). Localization and corruption: panacea or pandora's box? World Bank Policy Research 3486. http://down.aefweb.net/AefArticles/aef150103Gurgur.pdf

Halim, A. (2008). Dasar-Dasar Audit Laporan Keuangan. YKPN.

Hotho, J., Minbaeva, D., Muratbekova-Touron, M., \& Rabbiosi, L. (2018). Coping with favoritism in recruitment and selection: a communal perspective. Journal of Business Ethics, 165, 1-21. https://doi.org/10.1007/s10551-018-4094-9

Hughes, R. (2010). Passage of Change: Chapter Corruption. Law, Society and Governance in the Pacific: ANU Press. https://www.jstor.org/stable/j.ctt24h3jd.11

Kasim, A. (2013). Bureaucratic Reform and Dynamic Goernance for Combating Corruption: The Challenge for Indonesia. BISNIS \& BIROKRASI: Jurnal IImu Administrasi Dan Organisasi, 20(1). https://doi.org/10.20476/jbb.v20i1.1862 
Katharina, R. (2018). Reformasi Manajemen Aparatur Sipil Negara: Evaluasi Peran Pejabat Pembina Kepegawaian dan Komisi Aparatur Sipil Negara. Spirit Publik: Jurnal Administrasi Publik, 13(2), 1-15. https://doi.org/10.20961/sp.v13i2.24864

Kellough, J. E. (1999). Reinventing public personnel management: Ethical implications for managers and public personnel systems. Public Personnel Management, 28(4), 655671. https://doi.org/10.1177/009102609902800411

Khatri, N., \& Tsang, E. W. K. (2003). Antecedents and consequences of cronyism in organizations. Journal of Business Ethics, 43(4), 289-303. https://doi.org/10.1023/A:1023081629529

Ko, K., \& Weng, C. (2012). Structural changes in Chinese corruption. The China Quarterly, 718-740. https://doi.org/10.1017/S0305741012000793

Komisi Aparatur Sipil Negara. (2019). Penilaian Penerapan Sistem Merit dalam Manajemen ASN di Instansi Pemerintah Tahun 2019. Komisi Aparatur Sipil Negara.

McCourt, W. (2007). The merit system and integrity in the public service. Public Integrity and Anti-Corruption in the Public Service Conference, Bucharest, 29, 30.

McCrudden, C. (1998). Merit principles. Oxford Journal of Legal Studies, 18(4), 543-579.

Nasir, M. (2019). Reformasi Sistem Rekrutmen Pejabat Dalam Birokrasi Pemerintah (Studi Kasus Rekrutmen Pejabat Eselon II di Provinsi Nanggroe Aceh Darussalam. Jurnal $\begin{array}{lllll}\text { Kebijakan Dan Manajemen } & \text { PNS, } & \text { 3(2). }\end{array}$ https://jurnal.bkn.go.id/index.php/asn/article/view/165

Nunberg, B. (1994). Experience with civil service pay and employment reform: An overview. In D. Lindauer \& B. Nunberg (Eds.), Rehabilitating government: Pay and employment reform in Africa (119-159). World Bank. http://go.worldbank.org/T7081C87X0

Paul, J. G. S. M. (2011). Impact Evaluation in Practice. The International Bank for Reconstruction and The Development/The World Bank.

Pearce, J. L. (2015). Cronyism and nepotism are bad for everyone: The research evidence. The Research Evidence. Industrial and Organizational Psychology, 8(1), 41-44. https://doi.org/10.1017/iop.2014.10

Pearce, J. L., Branyiczki, I., \& Bigley, G. A. (2000). Insufficient bureaucracy: Trust and commitment in particularistic organizations. Organization Science, 11(2), 148-162. https://doi.org/10.1287/orsc.11.2.148.12508

Prendergast, C., \& Topel, R. H. (1996). Favoritism in organizations. Journal of Political Economy, 104(5), 958-978. https://doi.org/10.1086/262048

Rauch, J. E., \& Evans, P. B. (2000). Bureaucratic structure and bureaucratic performance in less developed countries. Journal of Public Economics, 75(1), 49-71. https://doi.org/10.1016/S0047-2727(99)00044-4

Rossen, B. (1975). The Merit System in the United States Civil Service. A monograph for the Committee on Post Office and Civil Service House of Washington. Government Printing Office.

Schroth, P. W. (2006). Corruption and Accountability of the Civil Service in the United States. The American Journal of Comparative Law, 54, 553-579. https://www.jstor.org/stable/20454553

Scully, G. W. (1991). Rent-seeking in US government budgets, 1900-88. Public Choice, 70(1), 99-106.

Setyowati, E. (2014). Analisis Merit System Dalam Proses Rekrutmen dan Seleksi CPNS di Kota Malang (Rekrutmen dan Seleksi CPNS Tahun 2000). Disertasi. Universitas Indonesia Depok.

Shah, A. (2007). Performance accountability and combating corruption. Public Sector Governance And Accountability Series. World Bank.

Suyito, S., Effendi, D., Yudiatmaja, W. E., Ghani, N. A., \& Abd Wahab, M. A. (2018). Peranan dan kontribusi lembaga swadaya masyarakat dalam agenda pemberantasan korupsi di Indonesia: Studi di kota Tanjungpinang, Kepulauan Riau, Indonesia. Asian People Journal, 1(2), 146-161 https://journal.unisza.edu.my/apj/index.php/apj/article/view/73 
Tim Penulis Buku Pendidikan Anti Korupsi. (2011). Pendidikan Anti-Korupsi Untuk Perguruan Tinggi. Kementerian Pendidikan dan Kebudayaan RI Direktorat Jenderal Pendidikan Tinggi.

Tjiptoherijanto. (2019). Reform of the Indonesian Civil Service: Looking for Quality. Journal of US-China Public Administration, 16(2), 56-66. https://doi.org/10.17265/23287144/2018.06.002

Tong, C. H., Straussman, J. D., \& Broadnax, W. D. (1999). Civil service reform in the People's Republic of China: case studies of early implementation. Public Administration and Development: The International Journal of Management Research and Practice, 19(2), 193-206.

World Bank. (2019). World Economic Forum (WEF), Government Effectiveness Index (GEI). https://tcdata360.worldbank.org/indicators/h8125e315

Yudiatmaja, W. E. (2016). Liberalisasi pendidikan tinggi di Indonesia. Dialektika Publik 1(2), 107-124 